911.3: 796.5(477)

\author{
льськ , у утинський \\ ввівський н ціон льний університет імені в н $в$ нк, \\ вул. . орошенк, 41, м. ьвів, 79000, кр їн
}

пис но процес ст новлення т основні ет пи розвитку к федри туризму ьвівського н ціон льного університету імені в н р нк . ет льно сх р ктеризов но б зові н прями досліджень к федри, оцінено внесок кожного з н уковців к федри у формув ння її н укового доробку, кцентов но ув гу н основних моногр фіях, н вч льних посібник х і підручник х, підготовлених колективом к федри з ост нні дев'ять років.

лючові слов : к федр туризму, ет пи розвитку, н уков спеці ліз ція.

ісля проголошення держ вної нез лежності кр їни т переходу кр їни до ринкової економіки й політики “відкритих" кордонів бр к ф хівців-орг ніз торів туризму у н шій держ ві відчув вся особливо гостро. ьвівський н ціон льний університет імені в н p нк ст в одним з перших вищих н вч льних з кл дів 3 хідного регіону держ ви, що у відповідь н кту льні суспільні з пити з поч ткув в підготовку нової генеp ції кв ліфіков них ф хівців - орг ніз торів і упр влінців міжн родного й внутрішнього туризму.

ершими крок ми у спр ві підготовки кв ліфіков них туристичних к дрів н геогр фічному ф культеті університету було відкриття у 1998 р. нової н вч льної спеці ліз ції “менеджмент туристичної індустрії” н б зі к федри геогр фії кр їни т створення міжк федр льного егіон льного ресурсного центру н вч льних м тері лів 3 туризму (координ тор . інько).

огічним з вершенням процесу орг ніз ційного ст новлення н ф культеті структурного підрозділу з усебічної підготовки кв ліфіков них ф хівців туристичної сфери ст ло створення окремої $\kappa$ федри туризму.

федр туризму орг нізов н згідно 3 к зом ректор ьвівського н ціон льного університету імені в н р нк № 194 від 4.02.2003 р. “" ро створення к федри туризму н геогр фічному ф культеті” н підст ві відповідної ухв ли ченої р ди ьвівського н ціон льного університету імені в н р нк від 29.01.2003 р. (протокол № 21/1).

рг ніз ційно к федр туризму пост л вн слідок поділу к федри геогр фії кр їни шляхом перерозподілу шт тних пос д професорсько-викл д цького т н вч льнодопоміжного персон лу т перед чі потоків студентів, які здобув ли ф х з спеці ліз цією “менеджмент туристичної індустрії”.

$\boldsymbol{m} \boldsymbol{n} \mathbf{c m}$ новлення к федри туризму хронологічно можн окреслити д т ми 31.01 . $-01.09 .2003 \mathrm{p}$.

() льськ ., утинський ., 2012 
т ном н 31.01.2003 р. - перший день офіційного функціонув ння к федри - тї н уково-пед гогічний персон л був т кий: з відув ч к федри, к нд. екон. н ук, доц. рт илипівн льськ, к ндид ти геогр фічних н ук, доценти ндрій теп нович ов льчук, т лія иросл вівн ньків, их йло осипович утинський, систент кс н икол ївн т ляк. ід поч тку перед з відув чем т пр цівник ми новоствореної к федри пост ли непрості з вд ння орг ніз ції н вч льного процесу, підготовки п кет н вч льно-методичного з безпечення згідно зі структурою й вимог ми н вч льного пл ну, підготовки п кетів документів для ліцензув ння т кредит ції спеці лі3 ції “менеджмент туристичної індустріі”, обгрунтув ння необхідності збільшення ліцензов ного обсягу підготовки ф хівців туристичної сфери, ремонту й обл штув ння приміщення к федри, н л годження п ртнерств із підприємств ми туристичного бізнесу т н уково-освітніми з кл д ми туристичного профілю тощо. вдяки н полегливій позиції . льської упродовж березня-вересня викл д цький т н вч льно-допоміжний персон л к федри збільшився удвічі. ісля успішного з хисту к ндид тських дисерт цій шт т к федри туризму поповнили теп н в нович енюк т гор ригорович ндяк, 3 сумісництвом н пос ди доцентів 3 р хов но упр влінців-пр ктиків ндрія олодимирович лім шевського і н толія рійович 6 рило, з 1 вересня 2003 р. н пос ди систентів 3 р хов ні т лія их йлівн нич, 'ячесл в олодимирович рмолович, к нд. геогр. н ук рест ріївн ордун, к нд. геогр. н уК их йло енонович мк ло. ступний $\boldsymbol{e m} \boldsymbol{n}$ розбудови к федри туризму прип в н друге півріччя 2003-друге півріччя 2005 рр. еред чільних здобутків к федри цього періоду:

- отрим ння ліцензій у іністерстві освіти і н уки кр їни й відкриття н геогр фічному ф культеті підготовки 6 к л врів, спеці лістів і м гістрів 3 н прямом “туризм";

- збільшення обсягу підготовки студентів туристичного ф ху (з спеці ліз ціями “менеджмент туристичної індустрії” т “туризм”) з однієї к демічної групи до чотирьох (із щорічним сукупним н бором пон д 120 студентів денної й з очної форм н вч ння);

- 3 поч ткув ння підготовки викл д ч ми к федри туризму т інших структурних підрозділів університету ф хівців у г лузі туристичної індустрії з кв ліфік ційним рівнем спеці ліст спеці ліз ції “менеджмент туристичної індустрії” у системі нституту післядипломної освіти ьвівського н ціон льного університету імені в н

- укл д ння угод між к федрою туризму т туристичними фірм ми і готелями м. ьвов про проходження н їхній б зі виробничих пр ктик студентів, орг ніз ція регіон льних т міжн родних н вч льних пр ктик студентів к федри туризму у ольщі й інших кр їн х ;

- підготовк й вид ння перших в кр їні укр їномовних підручників, н вч льних посібників і курсів лекцій з пит нь теорії і пр ктики туризму: “ енеджмент туризму” [30], “ снови туристичного бізнесу” [34, 35], “ еогр фія туризму кр їни” [47], “ екре логія з основ ми курортології” [50], “ л нув ння діяльності туристичних підприємств” [19], “ рг ніз ція і технологія обслуговув ння туристів туристичною фірмою” [14] т ін;

- уч сть викл д чів к федри у пон д десяти міжн родних н уково-пр ктичних конференціях туристичного профілю, вид ння близько трьох десятків ст тей з кту льних проблем туризму т серії н вч льно-методичних публік цій;

- уч сть н уковців к федри . льської, . утинського, . ндюк у престижному міжн родному дослідницькому проекті AUCI “ уристичний потенці л хідної 
кр їни” (координ тор з боку кр їни - . . інько), з результ т ми якого в 2005 р. у рш ві вийшл фунд мент льн колективн моногр фія "Potencjal turystyczny Ukrainy Zachodniej" [57];

- pe ліз ція н уково-дослідних проектів у р мк х годи про співробітництво між ьвівським н ціон льним університетом імені в н р нк, ерж вною туристичною дміністр цією кр їни т соці цією н вч льних з кл дів кр їни туристичного і готельного профілю;

- н л годження п ртнерських відносин з рш вським, роцл вським т геллонським університет ми, рш вським інститутом туризму, д нською вищою школою готелярств і туризму;

- урядов н город з відув ч к федри туризму . льської - н грудний зн к “ очесний пр цівник туризму кр їни” (2004).

огічним підсумком ет пу розбудови к федри туризму ст ло зрост ння кількості шт ту н уково-пед гогічного персон лу з вдяки з лученню перспективних молодих н уковців. осени 2005 р. н систентські пос ди з результ т ми н вч ння в спір нтурі 3 р хов но випускників к федри туризму 3 p юбомирович ндюк і лію легівну сюк, випускник к федри геогр фії кр їни ндрія их йлович ньк , випускницю ф культету міжн родних відносин рину теп нівну урську.

ступний період функціонув ння к федри туризму можн озн чити як $\boldsymbol{e m} \boldsymbol{n} \boldsymbol{\partial u \boldsymbol { \mu }}$ мічного зрост ння. ронологічно він укл д єТься в р мки 2006-2010 р. еред чільних здобутків к федри цього періоду:

- підготовк $з$ відув чем к федри докторського дисерт ційного дослідження;

- $з$ хист к ндид тських дисерт цій п'ятьм викл д ч ми к федри туризму;

- проходження пр цівник ми к федри трив лих міжн родних н укових ст жув нь в університет х і ортуг лії ( . уйцик) т ольщі ( . льськ, . удл, . мк ло, . утинський, . ов лко);

- відкриття к федр льної л бор торії “ вч льн туристичн генція” з метою формув ння у студентів професійних умінь т пр ктичних н виків роботи з обр ною спеці льністю;

- підготовк й вид ння серії підручників і н вч льних посібників з пит нь теорії і пр ктики туризму й готельного бізнесу: “ уристичний бізнес: теорія т пр ктик ” [31], “ отельний бізнес: теорія т пр ктик ” $[24,25]$, “ іжн родний туризм і сфер послуг” [16], “ ільський туризм” [52], “ мковий туризм в кр їні” [48], “ сторія туризму” [42], “ уристичне кр їнозн вство. вроп ” [21-23], “ уристичне кр єзн вство” [43], “ узеєзн вство” [53], “ л нув ння туристичної діяльності” [20], “ кту льні проблеми упр вління туристичною індустрією” [28], які використовують у н вч льному процесі в більшості вищих н вч льних з кл дів кр їни туристичного і готельного профілю;

- уч сть викл д чів к федри у пон д двох десятк х міжн родних н уково-пр ктичних конференцій туристичного профілю, вид ння близько сотні ст тей і тез доповідей з кту льних проблем туризму, т кож серії н вч льно-методичних публік цій;

- орг ніз ція викл д ч ми т студент ми К федри низки спортивно-туристичних спл вів, гірськолижних тренінгів і к тегорійних гірських піших походів (координ тори - доценти . мк ло, . он стирський, . ом нів), т кож н вч льно-екскурсійних студентських турів кр їною т терен ми від ольщі й горщини до т лії т р нції (координ тори - доценти . ордун, . мк ло, . утинський);

- укл д ння низки нових двосторонніх п ртнерських угод про творчу співпр цю з н уковими інституціями держ в ( веція, ольщ, горщин ); 
- проведення у 2007 р. предст вницького міжн родного н укового семін ру “ тежк ми в н р нк ”, присв’яченого 150-річчю від дня н родження письменник ;

- орг ніз ція з 2007 р. щорічних міжн родних н уково-пр ктичних конференцій “ еогр фія і туризм: європейський досвід” з уч стю провідних н уковців ольщі, лов ччини, , ілорусі т кр їни;

- відзн чення у 2008 р. першого 5-річного ювілею к федри туризму т вид ння до цієї урочистої д ти колективної моногр фії “ уризм у міжн родному і н ціон льному вимір х. сторія і суч сність" [29];

- обр ння у 2008 р. доц. . ндяк (з ступник з відув ч к федри туризму) н пос ду з ступник дек н геогр фічного ф культету ьвівського н ціон льного університету імені в н $\mathrm{p}$ нК.

продовж ет пу дин мічного зрост ння шт т н уково-пед гогічного персон лу к федри туризму двічі суттєво поповнюв вся з вдяки з лученню перспективних молодих н уковців (рис. 1). окрем , 2007 р. н систентські пос ди з р хов но вихов нців геогр фічного ф культету ьвівського н ціон льного університету імені в н $\mathrm{p}$ нк льгу горівну уйцик, митр н толійович дніч нського, олодимир ом нович он стирського, вл олодимирович ом нів . 2008-2010 pp. 3 результ т ми н вч ння в спір нтурі 3 сумісництвом н систентські пос ди 3 р хов но л бор нтів к федри туризму офію силівну ілоус, p c огд нович в довського, нну огд нівну ов лко т спір нтку лекс ндру икол ӥвну ушнірчукт вничу.

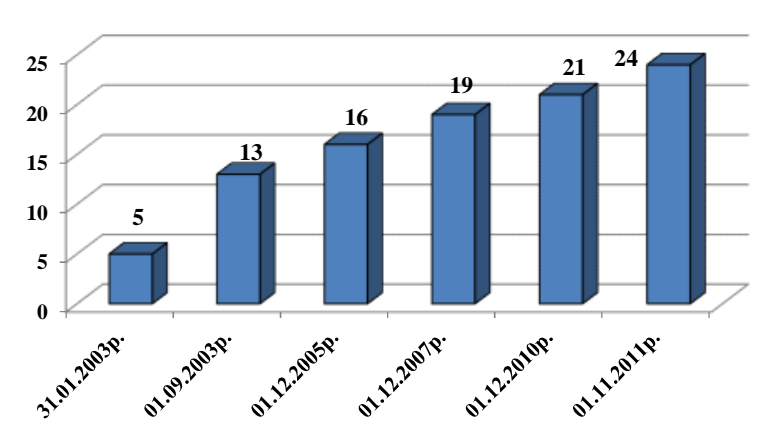

ис. 1. ин мік кількості шт ту н уково-пед гогічного персон лу к федри туризму у 20032011 pp., осіб.

yи сний em n розвитку к федри туризму логічно з поч ткув ти д тою з хисту з відув чем к федри . льською дисерт ційного дослідження н тему “ ормув ння і розвиток просторових систем послуг (теорія т пр ктик ре ліз ціі)” й здобуття н укового ступеня доктор економічних н ук. підст ві дисерт ційного дослідження вид но моногр фію “ росторові системи послуг (теорія, методологія, пр ктик )” [15].

зн к ми суч сного ет пу ст лого розвитку є всеукр їнське й міжн родне визн ння к федри туризму чільним у з хідному регіоні кр їни н уково-пед гогічним підрозділом ьвівського н ціон льного університету імені в н р нк у сфері туристичної освіти й н уки. федр утримує н йвищий рейтинг серед інших к федр і вищих н вч льних з кл дів з хідного регіону кр їни з :

- індексом конкурсного н бору серед бітурієнтів н н прям підготовки “туризм”; 
- обсягом вид ння н вч льної літер тури з теорії і пр ктики туризму із грифом іністерств освіти ін уки, молоді т спорту кр їни;

- якісними критеріями підготовки висококв ліфіков них ф хівців (б к л врів, спеці лістів і м гістрів) туристичної г лузі;

- пок зником ре льного пр цевл штув ння з ф хом випускників к федри у туристичних фірм х, екскурсійних бюро, готельних з кл д х, орг н х держ вного упр вління міст ьвов т $з$ хідного регіону держ ви.

осені 2011 р. шт т н уково-пед гогічного персон лу к федри туризму поповнився кр щими випускник ми м гістр тури - риною еновіївною ук т льгою етрівною іл нюк. тже, ст ном н 20.11.2011 колектив к федри туризму скл д ється з 24 викл д чів (рис. 2, див. вкл. 9). нтелекту льний потенці л к федри є її основним н дб нням і з порукою ст лого розвитку у структурі геогр фічного ф культету ьвівського н ціон льного університету імені в н $\mathrm{p}$ нК .

тр тегічними цілями под льшого розвитку к федри туризму є тісн інтегр ція н уки з пр ктикою туристичного бізнесу, н уково-методичне з безпечення місиевих ініці тив розвитку туризму н ввівщині, н укове проп гув ння н з кордонних форум х туристичних можсливостей кр їни, керівництво регіон льними й міжн родними н уково-дослідними проект ми з усебічного вивчення, інвент риз ції й експертнопрогностичної оцінки н явного в регіоні потенці лу для розбудови модерної туристичної індустрії н рівні суч сних європейськихвимог і $\mathrm{cm}$ нд ртів.

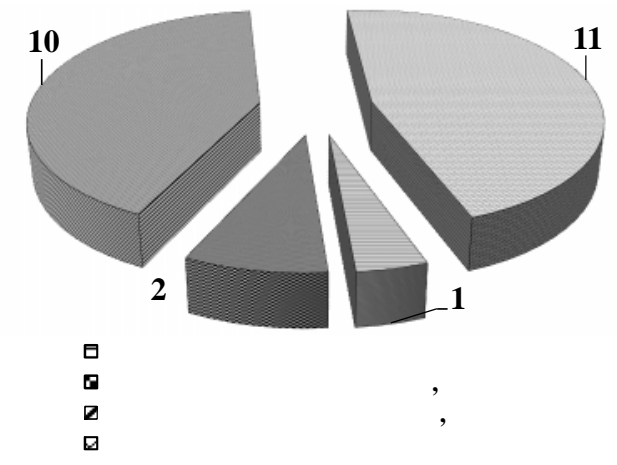

ис. 2. труктур шт ту н уково-пед гогічного персон лу к федри туризму ст ном н 01.11.2011 p., ociб.

продовж ост нніх восьми років н к федрі туризму сформув лися й дин мічно розвив ються дв н дцять основних н прямів досліджень, с ме: просторові системи послуг у сфері туризму; менеджмент і м ркетинг туризму; орг ніз ція й пл нув ння туризму; історія туризму; геогр фія туризму; рекре логія т рекре ційн геогр фія; туристичне кр їнозн вство й міжн родний туризм; туристичне кр єзн вство; менеджмент і орг ніз ція готельного бізнесу; туристично-рекре ційний потенці л кр їни; орг ніз ція екологічного і сільського туризму; орг ніз ція ктивних видів туризму. г льне керівництво й потужний імпульс розвитку н зв них н прямів досліджень з д є з відув ч к федри, доктор економічних н ук . льськ . 
. льськ координує розвиток усіх н прямів, що їх розробляють пр цівники к федри для формув ння львівської н укової школи туризму і сфери послуг. я стр тегічн ціль досяг ється з вдяки високій пр цезд тності. відченням чого є, зокрем , ст тистик вид нь . льськоюн в вч льної літер тури (т бл. 1):

блиця 1

ин мік вид нь н вч льної літер тури з відув чем к федри туризму

\begin{tabular}{|c|c|c|c|c|}
\multicolumn{2}{|c|}{ ИН мік вид нь н вч льної літер тури з відув чем к федри туризму } \\
\begin{tabular}{|c|c|c|c|} 
ік \\
вид ння
\end{tabular} & $\begin{array}{c}\text { ількість } \\
\text { н вч. посібників, } \\
\text { підручників }\end{array}$ & $\begin{array}{c}\text { ількість } \\
\text { моногр фій } \\
\text { обсяг, с. }\end{array}$ & $\begin{array}{c}\text { омер у списку } \\
\text { літер тури }\end{array}$ \\
\hline 2002 & 1 & & 295 & {$[30]$} \\
\hline 2003 & 1 & & 360 & {$[35]$} \\
\hline 2004 & 1 & & 272 & {$[34]$} \\
\hline 2005 & 1 & & 241 & {$[19]$} \\
\hline 2006 & 2 & & 250 & {$[31]$} \\
\hline 2007 & 1 & 1 & 924 & {$[16,29]$} \\
\hline 2008 & 1 & 1 & 1059 & {$[15,22,24]$} \\
\hline 2009 & 2 & & 1006 & {$[20,23,25]$} \\
\hline 2010 & 3 & & 968 & {$[1,27,33]$} \\
\hline 2011 & 3 & & 1909 & {$[17,18,26,32]$} \\
\hline 2012 & 6 & & &
\end{tabular}

ким чином, з ост ннє десятиріччя з відув чем к федри опубліков но 24 книги сум рним обсягом 7713 сторінок (456 др. ркушів).

. льськ очолює рейтинг пр цівників к федри туризму з з г льною кількістю публік цій - ст ном н 1.11.2011 р. їх н лічується 187. ругу позицію в рейтингу посід є н ймолодший із з хищених учнів . льської - . нько - із близько 150 позиціями вторського списку публік цій (у тім числі з т ких кту льних н прямів як спор-тивний туризм, туристичне кр єзн вство т філософія туризму).

йгрунтовніше розвиненим н прямом досліджень к федри туризму є просторові системи послуг у сфері туризму. ей н прям, по суті, уже переріс у н укову школу д-р екон. н ук . льської. н зв ною тем тикоюз відув чем к федри опубліков но близько п’ятдесяти ст тей і тез доповідей, вид но фунд мент льні моногр фії “ росторові системи послуг (теорія, методологія, пр ктик )" [15] і "Potencjal turystyczny Ukrainy Zachodniej” [57], підручник “ іжн родний туризм і сфер послуг” [16], з хищено дисерт цію н здобуття н укового ступеня доктор економічних н ук з спеці льністю 08.00.05.

прям поляг є в дослідженні суч сних теоретичних, методологічних і прикл дних з с д орг ніз ції т функціонув ння просторових систем послуг в умов х тр нсформ ційної соці льно орієнтов ної економіки. оловну ув гу в дослідженнях систем послуг у сфері туризму приділено вивченню регіон льних особливостей просторової орг ніз ції систем послуг у меж х ьвівської обл. т хідного регіону кр їни. н чну ув гу т кож зосереджено н висвітленні т ких спектів, як:

- системн методологія вивчення просторової орг ніз ції суспільств ,

- вз ємозв'язок розвитку послуг із функціонув нням суспільно-просторових систем,

- суспільно-економічні основи вивчення функціонув ння, розвитку т просторової орг ніз ції систем послуг, 
- теоретичні з с ди розміщення послуг і формув ння т функціонув ння просторових систем послуг,

- сфер послуг у системі н ціон льної економіки кр їни,

- формув ння просторових систем послуг в умов х ринкової тр нсформ ції н ціон льної економіки кр їни,

- просторово-функціон льн сегмент ція ринку послуг,

- тр нсформ ційні чинники розвитку просторових систем послуг,

- порівняльний н ліз функціонув ння т просторової орг ніз ції систем послуг регіону,

- основні н прями вдоскон лення просторової орг ніз ції систем послуг н н ціон льному т регіон льному рівнях,

- сутність і роль туризму в розвитку суспільних просторових систем,

- тенденції розвитку туризму в світовій системі послуг,

- н прями вдоскон лення держ вного регулюв ння розвитку просторових систем туристичних послуг т ін.

ступним 3 пріоритетністю н прямом досліджень к федри туризму є менеджмент готельного бізнесу. чолюють цей н прям . льськ т . НДяк, т кож н д цією проблем тикою ктивно пр цює . нич. ит ння 3 г льної теорії готельного бізнесу курує . льськ , дослідження - ндяк охоплюють пит ння упр вління, м ркетингу і технологічних з с д готельного бізнесу, проблемних спектів якості готельного сервісу тощо [24-27, 39 т ін.].

н зв ною тем тикою викл д ч ми к федри опубліков но пон д дв десятки ст тей і тез доповідей, поб чили світ фунд мент льні н вч льні вид ння “ рг ніз ція готельного обслуговув ння” і “ отельний бізнес: теорія т пр ктик” [24-27]. ст ння пр ця, зокрем , здобул н стільки широке міжн родне і всеукр їнське визн ння, що лише 3 ост нні роки з зн л трьох перевид нь [24-26] сукупним тир жем пон д три тисячі примірників і н сьогодні є одним з н йуспішніших вид вничих проектів к федри туризму.

рім н зв них, історичні спекти розвитку готельної індустрії грунтовно досліджують у ряді публік цій . ньків [29, 40, 42 т ін.] і . в довський [10 т ін.]; особливості територі льної орг ніз ції готельного господ рств висвітлює у низці публік цій . н нич $[7$ т ін.], як пр цює н д дисерт цією відповідної тем тики (н уковий керівник - . льськ ).

прям менеджмент, м ркетинг і пл нув ння туризму к федр туризму геогр фічного ф культету фунд мент льно розробляє з перших днів існув ння з огляду н ліцензов ну спеці ліз цію “менеджмент туристичної індустрії”, з якою з 2003 р. проводить підготовку студентів. чолює н прям . льськ .

н зв ною тем тикою з відув чем к федри у спів вторстві з іншими н уковцями опубліков но пон д сотню ст тей і тез доповідей, вид но серію фунд мент льних н вч льних посібників і підручників: “ енеджмент туризму” ( ьвів, 2002), “ снови туристичного бізнесу” ( ьвів, 2003, иїв, 2004), “ кту льні проблеми упр вління туристиною індустрією” ( ьвів, 2006), “ уристичний бізнес: теорія т пр ктик ” ( ., 2007, 2012), “ л нув ння діяльності туристичних підприємств” ( ьвів, 2003, ., 2005), “ л нув ння туристичної діяльності” ( ., 2010), “ рг ніз ція туристичного обслуговув ння” ( ., 2011), “ рг ніз ція т пл нув ння діяльності туристичних підприємств: теорія т пр ктик ” ( , , 2012). процесі підготовки н зв них пр ць сформув лися творчі зв'язки між к федрою туризму т н уковцями к федри міжн родного туризму і кр їно- 
зн вств ф культету міжн родних відносин ( . удо) й нституту післядипломної освіти ( . нько) ьвівського н ціон льного університету імені в н

вдяки лідерській позиції льської в розробці цього н пряму з діяно близько половини викл д цького скл ду к федри туризму. пецифіку пл нув ння і м ркетингу туризму досліджують . ндюк [57 т ін.], . ордун $[4,18-20]$, . рмолович $[56$ т ін. $]$.

д теоретичними і прикл дними особливостями менеджменту туристичного бізнесу під керівництвом · льської трив лий ч с пр цюють доценти . урськ [28, 44 т ін.], . ом нів [45 т ін.] т систенти-здобув чі н укового ступеня к ндид т еко-

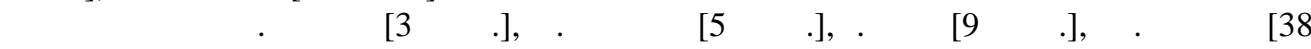
т iн.].

еред інших тр диційних профілів досліджень пр цівників к федри туризму в гомого розвитку н були історія туризму, геогр фія туризму, рекре логія т рекре ційн геогр фія, туристично-рекре ційний потенці л кр їни, туристичне кр їнозн вство і міжн родний туризм, туристичне кр єзн вство, орг ніз ція екологічного і сільського туризму.

прям туристичне кр їнозн вство і міжн родний туризм під керівництвом льської впродовж ост нніх років дин мічно розвив ється у тісній п ртнерській співпр ці к федри туризму геогр фічного ф культету з к федрою міжн родного туризму і кр їнозн вств ф культету міжн родних відносин т ф культетом міжн родного пр в і бізнесу нституту післядипломної освіти ьвівського н ціон льного університету імені в н р нк . езульт том цієї співпр ці є н вч льні вид ння: “ іжн родний туризм і сфер послуг” ( ., 2008), “ еоретичні основи кр їнозн вств” ( ., 2011) т “ р їнозн вство: теорія т пр ктик ” ( ., 2012) [1, 16, 17], до підготовки яких ктивно долучився ще один член к федри - сист. н нич.

ід керівництвом . льської й у спів вторстві з . утинським і . ньків вийшл у світ перш суто к федр льн колективн моногр фія “ уризм у міжн родному і н ціон льному вимір х. сторія і суч сність” [29]. окрему ув гу з слуговують регіон льні студії з туристичного кр їнозн вств . мК л й . ордун. Г тий теоретичний і пр ктичний досвід пон д двох десятиріч подорожей кр їн ми вропи д в змогу . льській з лучити . мк л й . ордун в ініці тивну групу й підготув ти н вч льний посібник з туристичного кр їнозн вств держ в вропи. ост нні декільк років цей посібник отрим в чим ло схв льних відгуків з різних регіонів кр їни, з зн в широкого тир жув ння т витрим в уже три вид ння ( ьвів, 2006, ., 2009, ., 2010) [21-23].

г д ний н прям т кож є у сфері н укових інтересів викл д чів к федри туризму . іл нюк, . уйцик, . нич, . т ляк, . ов льчук, . ньк , . он стирського, . ньків, . утинського, свідченням чого є ряд окремих публік цій цих н уковців у вісник х ьвівського, ернопільського, иївського університетів т збірник х н укових пр ць профільних інститутів.

прям туристичне кр єзн вство є профільним для к федри туризму геогр фічного ф культету і позиціонує іiі щодо іншого структурного підрозділу університету к федри міжн родного туризму і кр їнозн вств ф культету міжн родних відносин (де, н томість, профільним є туристичне кр їнозн вство). огляду н цю обст вину й тр диційні н укові з цік влення більшості пр цівників к федри, які пройшли життєвий шлях від студент до викл д ч геогр фічного ф культету, н д проблем тикою туристичного кр єзн вств нині пр цюють дві третини колективу к федри. ост нні вісім 
років туристично-кр єзн вч бібліогр фія пр цівників к федри н лічує пон д сімдесят публік цій. обсяг ми н укової продукції форм льне лідерство щодо розвитку н к федрі цього н пряму н лежить . утинському.

ільними туристично-кр єзн вчими н пр цюв ннями к федри є:

- $з$ с дничий н вч льний посібник “ уристичне кр єзн вство” ( ., 2006), у якому сформульов но об'єкт, предмет, цілі т поняттєво-термінологічний п р т туристичного кр єзн вств , т кож окреслено позицію цього н укового н пряму щодо кл сичних геогр фічного й історичного кр єзн вств [43];

- колективн польсько-укр їнськ моногр фія (з уч стю . льської, . утинського, · ндюк ) "Potencjal turystyczny Ukrainy Zachodniej” ( рш в , 2005), де вперше проведено інтегр льне туристичне р йонув ння обл стей хідної кр їни т про н лізов но суч сні територі льні диспропорції і перспективи розвитку в меж х досліджув ного регіону різних видів туристичної діяльності [57];

- грунтовн моногр фія . утинського й . тецюк “ уристичний комплекс рп тського регіону кр їни” ( ернівці, 2008), у якій обгрунтов но концепційно-теоретичні т методологічні з с ди дослідження туристичної сфери регіону, про н лізов но процеси її м сшт бних структурних тр нсформ цій т суч сної ринкової с моорг ніз ції у міжг лузевий туристичний комплекс, досліджено проблем тику вз ємодії т синергетичних ефектів розвитку тур гентського, готельного, с н торно-курортного, туристично-відпочинкового, рестор нного, розв ж льного бізнесу регіону, його прикордонної т комунік ційної інфр структури [54].

уристично-кр єзн вче дослідження олині є предметом дисерт ційної пр ці . т ляк, окремі результ ти їі туристично-кр єзн вчих розвідок опубліков но у близьо двох десятк х ст тей і тез н укових доповідей [8 т ін.].

лідно пр цюють н д туристично-кр єзн вчою проблем тикою викл д чі к федри ордун, · уйцик, · мк ло, · нич, · в довський, · дніч нський, ндюк, . нько, . сюк, . он стирський, . ндяк, . ньків, . ом нів, . ов лко, . рмолович.

н прямі історія туризму б г то років пров дять н укові дослідження й публікують тем тичну серію н укових розвідок, доповідей і ст тей доценти . ньків, . ов льчук і . утинський. еред основних історико-туристичних пр ць - курс лекцій “ сторія туризму” [42], перший розділ колективної моногр фії “ уризм у міжн родному і н ціон льному вимір х. сторія і суч сність” [29], перший розділ посібник “ уристичне кр єзн вство” [43], окремі публік ції у утинського у ч сописі “сторія укр їнської геогр фії” тощо.

p диційні н прями геогр фічних досліджень - геогр фія туризму, рекре логія т рекре ційн геогр фія, туристично-рекре ційний потенці л кр їни - з родилися ще в н уковому середовищі к федри геогр фії кр їни (н уков школ проф. . ст вного) і з 2003 року “перейшли" н новостворену к федру туризму, де н були под льшого розвитку і нині репрезентують геогр фічну скл дову н укових досліджень цього структурного підрозділу геогр фічного ф культету ьвівського університету.

прям геогр фія туризму є, по суті, міжк федр льним і м є б г торічні в гомі н пр цюв ння н уковців к федр економічної і соці льної геогр фії т геогр фії кр їни. ід ст ршої плеяди учених-геогр фів . щенк, . блія, . узик , . ст вного ест фету розвитку цього н пряму з 2003 р. перейняли молоді геогр фи новоствореної к федри туризму. 
чолює н прям . утинський. цією тем тикою опубліков но пон д дв десятки ст тей і тез доповідей, підготов но перший н терені держ ви посібник з цієї дисципліни $[46,47]$, пр цю “ ісце геогр фії туризму в структурі геогр фічної н уки, іï гносеологічн сутність т основні міждисциплін рні н прямки розвитку” [49] тощо.

д проблем тикою геогр фії туризму плідно пр цюють . мк ло, . нич, дніч нський, · нько, - он стирський, - ньків, · ом нів, · ов лко.

прям рекре логія $\boldsymbol{m}$ рекре ційн геогр фія - один 3 н йд вніших міжк федр льних н прямів н укової спеці ліз ції геогр фічного ф культету ьвівського університету. ктивн робот 3 н укового обгрунтув ння територі льної розбудови н 3 хідноукр їнських терен х рекре ційно-туристичного комплексу з поч тков н н прикінці 1960-1970-х рок х н уковцями к федри економічної геогр фії під керівництвом проф. щенк . прикінці 1970 - у 1980-ті роки ідеї . щенк н були под льшого розвитку у пр цях . ед шківської, передусім у моногр фії “ екре ційн систем кр їнських рп т” ( , , 1983). екре ційн геогр фія у стін х ьвівського університету зн йшл ктивних прихильників і серед н уковців природничо-геогр фічного профілю: професорів . тойк i . еренчук, доцентів . ожк , . едунь, . укурудзи, ушняк , . твіїв т ін. уч сний період розвитку геогр фічних досліджень рекре ції н йповніше репрезентов ний низкою пр ць . блія т . узик .

к федрі туризму цей н прям очолює . утинський. д ною тем тикою опубліков но пон д чотири десятки ст тей і тез доповідей, підготов но д птов ний для нової генер ції студентів (спеці ліз ції “менеджмент туристичної індустрії” т н пряму “туризм”) курс лекцій “ екре логія з основ ми курортології” [50]. кож плідно пр цюють н д рекре ційно-геогр фічною проблем тикою . ордун, . нич, . т ляк, нько, . ньків, у дотичній сфері рекре ційної економіки проводить дослідження . НДюк [37 т ін.].

прям туристично-рекре ційний потенці л кр ӥни т коже міжк федр льним і грунтується передусім н 6 г торічних в гомих н пр цюв ннях н уковців к федр геогр фії кр їни т економічної і соці льної геогр фії. рофесор . ст вний першим серед суч сних укр їнських геогр фів виокремив туристично-рекре ційний потенці л кр їни у с мостійний н прям перспективних геогр фічних досліджень і в низці пр ць окреслив його основні риси.

к федрі цей н прям очолює . ньків. цю тем тику опубліков но близько двох десятків ст тей і тез доповідей, вид но д птов ний для студентів спеці ліз ції “менеджмент туристичної індустрії” т н пряму “туризм” курс лекцій “ уристично-ресурсний потенці л кр їни” [41], н вч льний посібник “ уристичне ресурсозн вство” [41], в якому систем тизов но теоретичні з с ди т методичні підходи вчення про ресурсний туристично-рекре ційний потенці л, т кож зроблено всебічну оцінку усіх ресурсних скл дових туристичного потенці лу регіонів кр їни.

е менш плідно н д цією проблем тикою пр цюють . утинський [12, 51, 53 т ін.], . ндюк [57 т ін.], . мк ло [6,55 т ін.], . т ляк [8 т ін.].

прям екологічний $\boldsymbol{i}$ сільський туризм н геогр фічному ф культеті очолює очесний пр цівник туризму, олов спілки сільського зеленого туризму ьвівщини . інько, в шт тній структурі к федри туризму - . утинський. вдяки 6 г торічній творчій співпр ці . іньк , . утинського т інших експертів ост нніми рок ми вийшл низк н вч льних посібників і н уково-інформ ційних вид нь 3 проблем тики екологічного і сільського туризму, у тім числі “ ільський туризм” ( ., 2006), “ елений туризм” ( ., 2008), “ рг ніз ція т пл нув ння діяльності сільського туризму” ( дес , 
2009), “ вітовий досвід орг ніз ції сільського туризму” ( дес , 2009) тощо [11, 51, 52, 57 т ін.].

сфері екологічного туризму ктивно пр цюють . мк ло, . он стирський т . ом нів, кількість їхніх публік цій з проблем тики розвитку екологічного туризму в рп тському регіоні щороку зрост є.

прям спеці лізов ні види ктивного туризму й водноч с н йчисленніший студентський н уково-тренінговий гурток “ ктивний туризм” очолює . мК ло. орічно він орг нізовує декільк викл д цько-студентських спортивно-туристичних випр в у рп ти, пров дить проп г ндистську роботу серед студентського з г лу. ктульні проблеми розвитку ктивних видів туризму у хідному регіоні кр їни регулярно висвітлюють у співдоповідях н міжн родних н уково-пр ктичних конференціях . мк ло, . ордун, . ов лко, . ом нів, . он стирський, . нько [6, 55 т ін.]. . дніч нським розроблено іннов ційний курс лекцій “ олодіжний і н вч льний туризм” [13].

од льші перспективи розвитку к федри туризму. сьогодні к федр туризму є н йчисленнішим структурним підрозділом геогр фічного ф культету. е ст вить перед нею низку нових відповід льних з вд нь щодо гідного предст влення н уково-пед гогічного потенці лу геогр фічного ф культету, дотрим ння високих ст нд ртів якості, етики й тр дицій викл д цької м йстерності, збереження позиції лідер н ринку освітніх послуг регіону, вихов ння нової генер ції н ціон льно свідомої еліти кр їни, розвитку кту льних новітніх н прямів н укових студій н межі вз ємопроникнення геогр фічної й економічної н ук...

полі зору н уковців к федри н н йближчу перспективу - міждисциплін рні дослідження теоретичних т конкретних прикл дних проблем туристичного з господ рюв ння кр їнських рп т, ередк рп ття і к рп ття, прикордонних територій, окуття, озточчя, пілля, олині т оділля, т кож вивчення досвіду розвинених кр їн вропи, і передусім н ших н йближчих сусідів, щодо з пров дження ефективних ринкових мех нізмів держ вного т недерж вного стимулюв ння розвитку туристичної індустрії н місцевому і регіон льному рівнях; розвиток польсько-укр їнської співпр ці у туристичній сфері; вивчення пріоритетних осей (тр нспортно-туристичні коридори) т орг ніз ційних форм (м ле прив тне підприємництво, поліфункціон льні туристичні кл стери, територі льні екотуристичні утворення, вільні рекре ційно-туристичні зони тощо) розбудови суч сної туристичної інфр структури; м ркетингово-геогр фічні дослідження (вивчення геогр фії попиту н рекре ційно-туристичні послуги, геогр фії туристичного іміджу окремих р йонів тощо); геогр фії ринково-туристичної коньюнктури; геогр фії внутрішньо- т міжрегіон льної конкуренції місцевих турпродуктів тощо.

1. нтонюк . . еоретичні основи кр їнозн вств : підручник / . . нтонюк, . . льськ , . . нько, . . нич. - . : н ння, 2011. -326 с.

2. іл нюк . ункціон льно-територі льні особливості розвитку екологічного туризму в нор нківської обл сті / . іл нюк // еогр фія і туризм: міжн родні виклики укр їнського туризму: тері ли V міжн р. н ук. конф. ьвів- удов ишня, 23-25 вересня 2011. - ьвів: ид вничий центр ім. в н р нК , 2011. - .21-23.

3. ілоус . н ліз передумов розвитку туристичного бізнесу в кр їні / . ілоус // еогр фія і туризм: міжн родні виклики укр їнського туризму. тері ли $\mathrm{V}$ міжн р. н ук. конф. ьвів- 
удов ишня, 23-25 вересня 2011. - ьвів : ид вничий центр ім. в н p нк, 2011. .27-28.

4. ордун . . ослідження проблеми плинності к дрів н львівських туристичних фірм х т іï впливу н функціонув ння підприємств / . . ордун // еогр фія т туризм : зб. н ук. пр ць. . : льтерпрес, 2011. - ип. 14. - . 286-292.

5. уйцик .. п плив под ткового регулюв ння н розвиток рекре ційно-туристичного комплексу кр їни / . . уйцик // еогр фія і туризм: міжн родні виклики укр їнського туризму: теріли V міжн р. н ук. конф. ьвів- удов ишня, 23-25 вересня 2011. - ьвів : ид вничий центр ім. в н р нК, 2011. - .44-47.

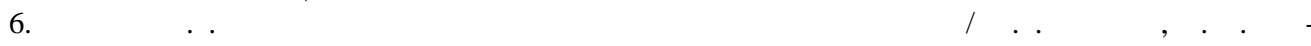
дун // ук. вісник ернів. ун-ту. - ернівці, 2010. - ип. 519-520: еогр фія. - . 121-124.

7. нич . . уч сні підходи до вдоскон лення якості готельних послуг в кр їні / . . нич // еогр фія т туризм : н ук. зб. / ред. кол.: . . лійник (відп. ред.) т ін. - . : льтерпрес, 2010. - ип. 10. - . .118-122.

8. $m$ ляк . . дміністр тивно-територі льний поділ як чинник історичного і соці льно-економічного розвитку олині / . . т ляк // кр їн : геогр фічні проблеми ст лого розвитку : зб. н ук. пр ць : у 4-х т. - . : брії, 2004. - . 2. - . 291-292.

9. $y \kappa .$. т н т тенденції розвитку м ркетингу н вітчизняних підприємств х туристичного бізнесу / . . ук // еогр фія і туризм: міжн родні виклики укр їнського туризму : тері ли V міжн р. н ук. конф. ьвів- удов ишня, 23-25 вересня 2011. - ьвів : ид вничий центр ім. в н р нК , 2011. - .66-69

10. в довський . . сторичні передумови формув ння і розвитку мережі з кл дів розміщення міст ьвов / . . в довський // еогр фія т туризм : зб. н ук. пр ць. - . : льтерпрес, 2011. - ип. 14. - . 195-199.

11. інько . . вітовий досвід орг ніз ції сільського туризму : н ук.-інформ. вид ння / . . iнько, . . сильєв, . . орішевський, . . утинський. - дес , 2009. - 56 с.

12. інько . . береження і ст лий розвиток рп т : н вч. посібник зі ст лого туризму / . . iнько, . . утинський, . . удл т ін./з ред. . тс кіорі, . лемп кі, . жер кіс. - ., 2009. $-60 \mathrm{c}$

13. дніч нський . . олодіжний і н вч льний туризм : курс лекцій / . . дніч нський. ьвів : ид вничий центр ім. в н р нк , 2010. -60 с.

14. ов льчук . . рг ніз ція і технологія обслуговув ння туристів туристичною фірмою: н вч.-метод. посібник / . . ов льчук. - ьвів : “ ", 2005. - 212 с.

15. льськ . . росторові системи послуг (теорія, методологія, пр ктик ) : моногр фія / . . льськ . - . : н ння, 2009. - 363 с.

16. льськ . . іжн родний туризм і сфер послуг : підручник / . . льськ , . . нтонюк, . . нич. - . : н н ння, 2008. - 661 с.

17. льськ . . $\mathrm{p}$ їнозн вство: теорія т пр ктик : підручник / . . льськ , . . нтонюк, . . нько, . . нич. - . : ентр учбової літер тури, 2012. - 528 с.

18. льськ. . рг ніз ція т пл нув ння діяльності туристичних підприємств : теорія т пр ктик : н вч. посібник / . . льськ , . . ордун. - . : ентр учбової літер тури, 2012. $241 \mathrm{c}$.

19. льськ . л нув ння діяльності туристичних підприємств : н вч. посібник / . . льськ , . . ордун. - . : н ння, 2005. - 241 с.

20. льськ . . л нув ння туристичної діяльності : підручник / . . льськ , . . ордун. - . : н ння, 2010. -310 с.

21. льськ . . уристичне кр їнозн вство. вроп : н вч. посібник / . . льськ, . . мк ло, . . ордун. - ьвів : ид вничий центр ім. в н р нк, 2006. -172 с.

22. льськ . . уристичне кр їнозн вство. вроп : н вч. посібник / . . льськ , . . мк ло, . . . ордун. - . : ентр учбової літер тури, 2009. -224 с.

23. льськ . . уристичне кр їнозн вство. вроп : н вч. посібник. 2-ге вид. / . . льськ , . . мк ло, . . . ордун. - . : ентр учбової літер тури, 2010. - 224 с. 
24. льськ . . отельний бізнес: теорія т пр ктик : н вч. посібник / . . льськ ,

. . н ндяк. - . : ентр учбової літер тури, 2009. - 472 с.

25. льськ . . отельний бізнес: теорія т пр ктик : підручник / . . льськ , . . дяк. - . : ентр учбової літер тури, 2010. - 472 с.

26. льськ . . отельний бізнес: теорія т пр ктик : підручник. 2-е вид. перероб. т доп. /

. . льськ , . . ндяк. - . : ентр учбової літер тури, 2012. -472 с.

27. льськ . . рг ніз ція готельного обслуговув ння : підручник / . . льськ , . .

дяк, . . нько. - . : н ння, 2011. - 367 с.

28. льськ . . кту льні проблеми упр вління туристичною індустрією : н вч. посібник /

. . льськ, . . урськ .- ьвів : ид вничий центр ім. в н р нк, 2006. -78 с.

29. льськ . . уризм у міжн родному і н ціон льному вимір х. сторія і суч сність : моногр фія / . . льськ , . . утинський, . . ньків. - ьвів : ид вничий центр ім. в н р нK , 2008. -268 c.

30. льськ . . енеджмент туризму. ступ до спеці льності : н вч. посібник / . . льськ , . . удо. - ьвів : ид вничий центр ім. в н р нк , 2002. -295 с.

31. льськ . . уристичний бізнес: теорія т пр ктик : н вч. посібник / . . льськ , . . удо. - . : ентр учбової літер тури, 2007. -424 с.

32. льськ . . уристичний бізнес: теорія т пр ктик : підручник. 2-ге вид. перероб. т доп.

/ . . л льськ , . . удо. - . : ентр учбової літер тури, 2012. -368 с.

33. льськ . . рг ніз ція туристичного обслуговув ння : підручник / . . льськ , . . . у-

до, . . нько. - . : н ння, 2011. - 275 с.

34. льськ . . снови туристичного бізнесу : н вч. посібник / . . льськ , . . удо,

. . ибух. - . : ентр учбової літер тури, 2004. -272 с.

35. льськ . . снови туристичного бізнесу : н вч. посібник / . . льськ , . удо, . . ибух. - ьвів : ид вничий центр ім. в н р нК, 2003. - 360 с.

36. нько . ільський туризм к рп тської обл сті / . нько, . конечний, . ичм // еогр фія і туризм: міжн родні виклики укр їнського туризму : тері ли V міжн р. н ук. конф. ьвів- удов ишня, 23-25 вересня 2011. - ьвів : ид вничий центр ім. в н р нк, 2011. - . .129-132.

37. ндюк . . н ліз ринку рекре ційних послуг гірських територій ьвівської обл сті / . . ндюк // егіон. економік . - 2006. - №1. - . 228-236.

38. сюк . н н ліз створення т використ ння неймів при формув нні бренду туристичної комп нії (н прикл ді підприємств туристичної г лузі кр їни) / . . сюк // еогр фія і туризм: міжн родні виклики укр їнського туризму : тері ли V міжн р. н ук. конф. ьвів- удов ишня, 23-25 вересня 2011. - ьвів : ид вничий центр ім. в н р нк, 2011. .137-141.

39. ндяк . . етодологічні принципи вдоскон лення процесу упр вління якістю готельних послуг / . . ндяк // існ. ьвів. ун-ту. ер. геогр. - ьвів, 2009. - ип. 36. - . 249-254.

40. ньків . уристичне ресурсозн вство: н вч. посібник / . . ньків. - ьвів : кр. бестселер, 2011. - 238 с.

41. ньків . . уристично-ресурсний потенці л кр їни : текст лекцій / . . ньків. - ьвів : ид вничий центр ім. в н р нК , 2006. - 72 с.

42. ньків . . сторія туризму: курс лекцій / . . ньків, . . ов льчук. - ьвів : ид вничий центр ім. в н р нк ,2006. -86 c.

43. етр нівський . уристичне кр єзн вство : н вч. посібник/з ред. проф. . . ст вного / . . етр нівський, . . утинський. - . : н ння, 2006. - 575 с.

44. урськ . пр вління якістю туристичного продукту в міжн родній діяльності підприємств / . урськ // еогр фія і туризм: міжн родні виклики укр їнського туризму : тері ли V міжн р. н ук. конф. ьвів- удов ишня, 23-25 вересня 2011. - ьвів : ид вничий центр ім. в н р нК, 2011. - .172-173.

45. ом нів . . пр вління регіон льним розвитком туризму : н вч.-метод. м тері ли / . . ом нів. - ьвів: ид вничий центр ім. в н р нК, 2009. - 78 с. 
46. утинський . . еогр фія туризму кр їни: н вч.-метод. посібник / . . утинський. ьвів : енікс, 2002. - 107 с.

47. утинський . . еогр фія туризму кр їни: н вч.-метод. посібник. ид. 2-ге, переробл. i доп. / . . у утинський. - . : ентр н вч. літер тури, 2004. - 160 с.

48. утинський . . мковий туризм в кр їні. еогр фія п м'яток фортифік ційного зодчеств т перспективи їх туристичного відродження : н вч. посібник / . . утинський. - . : ентр учбової літер тури, 2007. - 432 с.

49. утинський . . ісце геогр фії туризму в структурі геогр фічної н уки, їі гносеологічн сутність т основні міждисциплін рні н прямки розвитку / . . утинський // еогр фія т туризм : н ук. зб. /відп. ред. . . лійник. - . : льтерпрес, 2010. - ип. 6. - .96-101.

50. утинський . . екре логія з основ ми курортології. стин . еоретичні з с ди : курс лекцій / . . у утинський. - ьвів: енікс, 2004. - 68 с.

51. утинський . . елений туризм / . . утинський, . . інько. - . : н ння, 2008. - 271 с.

52. утинський . . ільський туризм : н вч. посібник / . . утинський, . . інько. - . : н ння, 2006. - 271 с.

53. утинський . . узеєзн вство: н вч. посібник / . . утинський, . . тецюк. - . : н ння, 2008. -428 с.

54. утинський . . уристичний комплекс рп тського регіону кр їни: моногр фія / . . утинський, . . тецюк. - ернівці : ниги - ,2008. - 440 с.

55. ов лко . . рстові печери оділля: ємність туристичних потоків, проблеми т перспективи використ ння / . . ов лко, . . мк ло // еогр фія. кономік . кологія. уризм: егіон. студії іжин. держ. ун-ту ім. иколи оголя. - іжин, 2009. - ип. 3. - . 171-176.

56. рмолович . . р ркетингове середовище регіону н ринку туристичних послуг / . . pмолович // еогр фія і туризм: міжн родні виклики укр їнського туризму. тері ли V міжн р. н ук. конф. ьвів- удов ишня, 23-25 вересня 2011. - ьвів : ид вничий центр p HK , 2011. - .219-222.

57. Potencjal turystyczny Ukrainy Zachodniej / Projekt PAUCI nr 00-0195-056 Potencjal turystyczny Ukrainy Zachodniej: Kierunki i mozliwosci inwestowania w sektorze turystyki w swietle polskich doswiadczen / R. Szczecinski, J. Zinko, R. Lozynski i in. - Warszawa: Instytut Turystyki, 2005. - 263 s.

m ття: н дійшл до редколегї 06.10.2011

прийнят до друку 20.11.2011

\section{PERIODS OF DEVELOPMENT OF DEPARTMENT OF TOURISM AT IVAN FRANKO NATIONAL UNIVERSITY OF LVIV}

\section{Malska, M. Rutynskyi}

Ivan Franko National University of Lviv, P. Doroshenko St., 41, UA - 7900, Ukraine

The article describes the process of formation and main stages of the Tourism Chair of the Ivan Franko Lviv National University. The authors described the basic research areas of the Tourism Chair in detail. The contribution each of the staff member is evaluated. The attention is drawn to basic scientific monographs, textbooks and books prepared by the staff of the Chair during last nine years.

Key words: Department of Tourism, periods of development, scientific specialisation. 


\section{. льск я, - утинский}

ввовский н цион льный университет имени в н р нко, ул. . орошенко, 41, г. ьвов, 79000, кр ин

пис но процесс ст новления и основные эт пы р звития к федры туризм ьвовского н цион льного университет имени в н р нко. одробно ох р ктеризов но б зовые н пр вления н учных исследов ний к федры туризм , д но оценку вкл д к ждого из ученых к федры в формиров ние ее н учного н следия, кцентиров но вним ние н основных моногр фиях, учебных пособиях и учебник х, подготовленных коллективом к федры 3 последние девять лет.

лючевые слов : к федр туризм , эт пы р звития, н учн я специ лиз ция. 